\title{
SOCIO-DEMOGRAPHIC CORRELATES OF OCULAR MORBIDITY IN SCHOOL CHILDREN OF RURAL HARYANA
}

\author{
Seema Sharma ${ }^{1}$, B. M. Vashisht², Satinder Vashisht ${ }^{3}$, Seema Chaudhary4, Neelu Saluja ${ }^{5}$, Suresh Kumar6, S. M. Pandey7 \\ ${ }_{1}^{1}$ Associate Professor, Department of Community Medicine, MAMC, Agroha, India. \\ 2Professor, Department of Community Medicine, PGIMS, Rohtak, India. \\ ${ }^{3}$ Senior Medical Officer, Regional Institute of Ophthalmology, PGIMS, Rohtak, India. \\ 4 Professor, Department of Community Medicine, MAMC, Agroha, India. \\ ${ }_{5}^{5}$ Associate Professor, Department of Community Medicine, MAMC, Agroha, India. \\ ${ }^{6}$ Medical Officer, Haryana Civil Medical Services, India. \\ ${ }^{7}$ Assistant Professor (Statistics), Department of Community Medicine, MAMC, Agroha, India.
}

\section{ABSTRACT}

\section{BACKGROUND}

Vision impairment and blindness in children are important because of their impact on the child's development, education, future work opportunities and quality of life. These negative effects are experienced throughout the child's life. It leads to serious social and economic burden to the family and the society.

This study was conducted with the objectives of estimating the prevalence of ocular problems among school going children in rural area and to study the association of ocular problem with socio-demographic factors.

\section{MATERIALS AND METHODS}

This cross-sectional study was done in Govt. Senior Secondary Schools of Block Lakhanmajra, Haryana. Out of 16 Govt. Senior Secondary Schools, 4 were randomly chosen. Students aged 6 - 15 years studying in class 1 to 10 were included in the study. Test performed were Visual acuity (Snellen's E-chart), Cover Test, Ocular motility and External examination by torch, lens and loupe and an interview was done on the basis of questionnaire. The findings of clinical examination were recorded on a pre-tested Performa. After collection, the whole data was compiled; analysed and appropriate statistical tests like simple proportions, chisquare $\left(\chi^{2}\right)$ test were applied.

\section{RESULTS}

Out of 1265 students $41.4 \%$ boys and $38.9 \%$ girls were suffering from one or more eye problems. Out of total 451 children (35.65\%) were having one or more eye problems; however, the overall prevalence of ocular morbidity was found to be $39.9 \%$. Defective vision was the commonest morbidity (13.6\%) followed by squamous blepharitis (12.3\%), vernal conjunctivitis (5.1\%), conjunctivitis $(4.7 \%)$, conjunctival xerosis $(2.8 \%)$, squint $(0.8 \%)$ and stye $(0.7 \%)$. Defective vision was significantly associated with girls. Squamous blepharitis was significantly associated with boys. Except defective vision all diseases were more prevalent in boys. Eye problems were found to be more among students whose father and mother were illiterate. Association of vernal conjunctivitis with father's literacy was found to be significant.

\section{CONCLUSION}

Ocular disorders among school going children can be easily identified by regular eye screening programmes. Prompt treatment can protect the child from future complications and blindness. The eye health awareness among children and school teachers should be improved.

\section{KEYWORDS}

Socio-Demographic, Ocular Morbidities, Rural Area, School Children.

HOW TO CITE THIS ARTICLE: Sharma S, Vashisht BM, Vashisht S, et al. Socio-demographic correlates of ocular morbidity in school children of rural Haryana. J. Evolution Med. Dent. Sci. 2017;6(16):1239-1243, DOI: 10.14260/Jemds/2017/269

\section{BACKGROUND}

The eyes are nature's meticulously designed most valuable gift for mankind. Eyes act as our windows to the world. Vision contributes greatly to one's learning capacities right since childhood. ${ }^{1}$ So it is important to take care of eyes during the

Financial or Other, Competing Interest: None.

Submission 17-01-2017, Peer Review 01-02-2017,

Acceptance 15-02-2017, Published 23-02-2017.

Corresponding Author:

Dr. Seema Sharma,

Associate Professor,

Department of Community Medicine,

Maharaja Agrasen Medical College,

Agroha, Hisar-125047,

Haryana, India.

E-mail: ss4_gunu@yahoo.co.in

DOI: $10.14260 /$ jemds $/ 2017 / 269$

\section{(c) $(i) \Theta$}

development of a child. The eyes can perform their function well only if their growth and development is well established. It is therefore essential that the common afflictions of the eyes that cause visual impairment or loss of eyesight are possibly prevented and properly treated. ${ }^{2}$

Childhood eye morbidity is defined as "Any eye disease or condition that requires ophthalmic care and treatment, which if untreated can often progress to serious and sight threatening disease."3

Around $80 \%$ of all visual impairment can be prevented or cured and that about $90 \%$ of the World's visually impaired live in developing countries. ${ }^{4}$

Poor vision in childhood affects performance in school or at work and has a negative influence on the future life of the child. 5

Most eye disorders do not manifest dramatic visual disability initially; hence, they may be detected at a late stage. 
If the disease affects a single eye quite often the patient is unaware of the defect until there is severe visual loss, so awareness programmes to educate the public regarding eye disorder is essential. ${ }^{2}$

With changing lifestyles eyes are under a lot of stress, younger children have much more to study. Increased use of computer, mobiles, long hours of television viewing and poor lighting all add to the problem.

Childhood blindness is a challenging problem in developing countries. In rural areas, neither the children nor the parents are intelligent enough to detect the eye problems and gradually these problems may result in blindness.

\section{MATERIALS AND METHODS}

The present cross-sectional study was carried out from September 2006 to July 2007 in Block Lakhanmajra, which is the field practice area attached to the Department of Community Medicine, Pt. B. D. Sharma Postgraduate Institute of Medical Sciences, Rohtak. The study subjects were school going children in the age group of 6 - 15 years. Out of total 16 Govt. schools existing in the block, two girls' schools and two boys' schools were randomly selected and all the students between 6 - 15 years of age, studying in class $1^{\text {st }}$ to $10^{\text {th }}$ were included in the study. The students were divided into three age groups: 6 - 10 years, $10-13$ years and $13-15$ years. All concerned Principals, Teachers and Students were briefed about the study. Each student was interviewed individually by the author in their local language, so that they can understand questions easily. The students present on day of visit were included in the study. No followup visits were done. The age of students was ascertained as per the school records. Visual Acuity (VA) test was performed using Snellen's E chart. If distant visual acuity was $<6 / 6$, then those students were subjected to refraction by ophthalmic assistant. $\mathrm{VA}<6 / 6$ was taken as criteria of defective vision, because criterion of low vision according to WHO (VA $\leq 6 / 18$ in better eye) is already grossly subnormal for school children.

Information was collected on a pre-tested semistructured schedule. After collection, the whole data was compiled; analysed (SPSS-10) and appropriate statistical tests like percentages and chi-square $\left(\chi^{2}\right)$ tests were applied.

\section{Inclusion Criteria}

All the Children in the age group of 6 - 15 years in the selected schools.

\section{Exclusion Criteria}

Those who are not responding well and absentees on the day of examination.

\section{RESULTS}

Table I shows the distribution of different eye problems.

Table II shows most of the morbidities were found in oldest age group (13 - 15 yrs.), while least morbidities in the youngest age group (6 - 10 yrs.). Strong significant association was found with increase in age group in cases of defective vision* and xerosis*.

Table III shows that $41.4 \%$ boys and $38.9 \%$ girls were suffering from one or more eye problem. Defective vision* was significantly associated with girls. Squamous blepharitis* was significantly associated with boys. Except defective vision, all diseases were more prevalent in boys as compared to girls.

Table IV shows that out of all only conjunctival xerosis* was associated significantly with caste, it was more prevalent in scheduled caste students.

Table $\mathrm{V}$ shows that eye problems were found to be maximum among students whose father was illiterate as compared to those whose father was literate. Association of vernal conjunctivitis* with father's literacy was found to be significant.

Table VI shows that eye problems were found to be maximum among students whose mother was illiterate as compared to those whose mother was literate. Association of vernal conjunctivitis* with mother's literacy was found to be borderline significant.

Table VII shows that farming and labour were common occupation of the area. Maximum no. of eye problems were found in students, whose fathers were labourer. Association of individual problems was calculated, but no significant association found.

\begin{tabular}{|c|c|c|}
\hline Eye Problems & Total $n=1265$ & Percentages [\%] \\
\hline Defective Vision & 172 & 13.6 \\
\hline Squamous Blepharitis & 156 & 12.3 \\
\hline Conjunctivitis & 59 & 4.7 \\
\hline Vernal Conjunctivitis & 64 & 5.1 \\
\hline Stye & 9 & 0.7 \\
\hline Squint & 10 & 0.8 \\
\hline Conjunctival Xerosis & 35 & 2.8 \\
\hline Total & 505 & 39.9 \\
\hline
\end{tabular}

\begin{tabular}{|c|c|c|c|c|c|c|c|c|}
\hline \multirow{2}{*}{$\begin{array}{c}\text { Age } \\
\text { Groups }\end{array}$} & $\begin{array}{c}\text { Defective } \\
\text { Vision [\%] }\end{array}$ & $\begin{array}{c}\text { Squamous } \\
\text { Blepharitis [\%] }\end{array}$ & $\begin{array}{c}\text { Conjunctivitis } \\
{[\%]}\end{array}$ & $\begin{array}{c}\text { Vernal } \\
\text { Conjunctivitis [\%] }\end{array}$ & $\begin{array}{c}\text { Stye } \\
{[\%]}\end{array}$ & $\begin{array}{c}\text { Squint } \\
{[\%]}\end{array}$ & $\begin{array}{c}\text { Conjunctival } \\
\text { Xerosis [\%] }\end{array}$ & $\begin{array}{c}\text { Total } \\
{[\%]}\end{array}$ \\
\hline $\begin{array}{c}6-10 \text { Years } \\
\text { N = 282 }\end{array}$ & $14[4.97]$ & $36[12.8]$ & $10[3.6]$ & $14[5.0]$ & $3[1.1]$ & $5[1.8]$ & $1[0.4]$ & $83[29.4]$ \\
\hline $\begin{array}{c}10-13 \text { Year } \\
\text { N = 536 }\end{array}$ & $56[10.45]$ & $62[11.6]$ & $23[4.3]$ & $30[5.6]$ & $3[0.6]$ & $4[0.75]$ & $16[2.99]$ & $194[36.2]$ \\
\hline $\begin{array}{c}13-15 \text { Years } \\
\text { N = 447 }\end{array}$ & $102[22.82]$ & $58[13]$ & $26[5.8]$ & $20[4.8]$ & $3[0.7]$ & $1[0.22]$ & $18[4.03]$ & $228[51]$ \\
\hline $\begin{array}{c}\text { Total } \\
\text { N = 1265 }\end{array}$ & $172[13.6]$ & $156[12.3]$ & $59[4.7]$ & $64[5.1]$ & $9[0.7]$ & $10[0.8]$ & $35[2.8]$ & $505[39.9]$ \\
\hline $\begin{array}{c}\chi 2 \text { Value } \\
\text { dff- } 2)\end{array}$ & 46.07 & 0.496 & 2.13 & 0.51 & 0.690 & 5.355 & 8.807 & \\
\hline P value & $<0.000^{*}$ & 0.78 & $>0.10$ & 0.50 & 0.70 & 0.07 & $0.012^{*}$ & \\
\hline \multicolumn{7}{|c|}{ Table II. Age Wise Distribution of Eye Problems } & \\
\hline
\end{tabular}




\begin{tabular}{|c|c|c|c|c|c|}
\hline \multirow{2}{*}{ Eye Problems } & \multicolumn{2}{|c|}{ Sex } & \multirow{2}{*}{$\begin{array}{l}\text { Total [\%] } \\
\mathrm{n}=1265\end{array}$} & \multirow{2}{*}{$\begin{array}{c}\chi^{2} \text { Value } \\
\text { (df-1) }\end{array}$} & \multirow{2}{*}{$\begin{array}{c}\mathbf{P} \\
\text { Value }\end{array}$} \\
\hline & Boys [\%] $n=510$ & Girls [\%] n = 755 & & & \\
\hline Defective Vision & $46[9.02]$ & $126[16.69]$ & $172[13.6]$ & 15.40 & $<0.000^{*}$ \\
\hline Squamous Blepharitis & 75 [14.7] & 81 [10.7] & $156[12.3]$ & 4.491 & $0.034^{*}$ \\
\hline Conjunctivitis & $30[5.9]$ & 29 [3.8] & 59 [4.7] & 2.65 & $>0.10$ \\
\hline Vernal Conjunctivitis & $33[6.5]$ & $31[4.1]$ & $64[5.1]$ & 3.35 & $>0.05$ \\
\hline Stye & $4[0.78]$ & $5[0.66]$ & $9[0.7]$ & 0.064 & 0.80 \\
\hline Squint & $5[0.98]$ & $5[0.66]$ & $10[0.8]$ & 0.393 & 0.531 \\
\hline Conjunctival Xerosis & $18[3.5]$ & $17[2.2]$ & $35[2.8]$ & 1.858 & 0.173 \\
\hline Total & $211[41.4]$ & 294 [38.9] & 505 [39.9] & & \\
\hline \multicolumn{6}{|c|}{ Table III. Sex Wise Distribution of Eye Problems } \\
\hline
\end{tabular}

\begin{tabular}{|c|c|c|c|c|c|c|}
\hline \multirow[b]{2}{*}{ Eye Problems } & \multicolumn{3}{|c|}{ Caste } & \multirow[b]{2}{*}{$\begin{array}{c}\text { Total } \\
\mathrm{n}=1265[\%]\end{array}$} & \multirow[b]{2}{*}{$\begin{array}{c}\chi^{2} \\
(\mathrm{df}-2)\end{array}$} & \multirow[b]{2}{*}{$\begin{array}{c}\mathbf{p} \\
\text { Value }\end{array}$} \\
\hline & $\begin{array}{c}\text { Backward Class } \\
n=291[\%]\end{array}$ & $\begin{array}{c}\text { General Caste } \\
n=551[\%]\end{array}$ & $\begin{array}{c}\text { Scheduled Caste } \\
n=423[\%]\end{array}$ & & & \\
\hline Defective Vision & $32[11]$ & $85[15.4]$ & $55[13.0]$ & $172[13.6]$ & 3.40 & $>0.1$ \\
\hline Squamous Blepharitis & 36 [12.4] & 68 [12.3] & 52 [12.3] & 156 [12.3] & 0.001 & 1.00 \\
\hline Conjunctivitis & $8[2.8]$ & $25[4.5]$ & $26[6.2]$ & 59 [4.7] & 4.63 & 0.10 \\
\hline Vernal Conjunctivitis & $15[5.2]$ & $28[5.1]$ & $21[5.0]$ & $64[5.1]$ & 0.02 & $>0.50$ \\
\hline Stye & $1[0.3]$ & $5[0.9]$ & $3[0.2]$ & $9[0.7]$ & 0.852 & 0.653 \\
\hline Squint & $0[0.0]$ & $5[0.9]$ & $5[1.2]$ & $10[0.8]$ & 3.249 & 0.197 \\
\hline Conjunctival Xerosis & $9[3.1]$ & $8[1.5]$ & $18[4.3]$ & $35[2.8]$ & 7.166 & $0.028^{*}$ \\
\hline Total & $101[34.7]$ & $224[40.7]$ & $180[42.6]$ & 505 [39.9] & & \\
\hline \multicolumn{7}{|c|}{ Table IV. Caste Wise Distribution of Eye Problems } \\
\hline
\end{tabular}

\begin{tabular}{|c|c|c|c|c|c|c|c|c|}
\hline \multirow[b]{2}{*}{$\begin{array}{c}\text { Eye } \\
\text { Problems }\end{array}$} & \multicolumn{5}{|c|}{ Father's Literacy } & \multirow[b]{2}{*}{$\begin{array}{c}\text { Total } \\
\mathbf{n}=1223 \\
{[\%]}\end{array}$} & \multirow[b]{2}{*}{$\begin{array}{c}\chi^{2} \\
(d f-4)\end{array}$} & \multirow[b]{2}{*}{$\begin{array}{c}\mathbf{P} \\
\text { Value }\end{array}$} \\
\hline & $\begin{array}{c}\text { Illiterate } \\
\mathbf{n}=257 \\
{[\%]}\end{array}$ & $\begin{array}{c}\text { Primary } \\
n=193 \\
{[\%]}\end{array}$ & $\begin{array}{c}\text { Middle } \\
\text { n = 270 } \\
{[\%]}\end{array}$ & $\begin{array}{c}\text { Matric } \\
\text { n= 349 } \\
{[\%]}\end{array}$ & $\begin{array}{c}\text { zIntermediate } \\
\mathrm{n}=\mathbf{1 5 4} \\
{[\%]}\end{array}$ & & & \\
\hline Defective Vision & $36[14]$ & $28[14.5]$ & 40 [14.8] & 39 [11.2] & 19 [12.3] & $162[13.3]$ & 4.78 & 0.869 \\
\hline $\begin{array}{l}\text { Squamous } \\
\text { Blepharitis }\end{array}$ & 33 [12.8] & $27[14.4]$ & 26 [9.6] & 43 [12.3] & 22 [14.3] & $151[12.4]$ & 3.313 & 0.855 \\
\hline Conjunctivitis & $11[4.3]$ & $5[2.6]$ & $16[5.9]$ & $17[4.9]$ & $7[4.5]$ & $56[4.6]$ & 3.34 & $>0.1$ \\
\hline $\begin{array}{c}\text { Vernal } \\
\text { Conjunctivitis }\end{array}$ & $17[6.6]$ & $6[3.1]$ & $12[4.4]$ & 17 [4.9] & $9[5.8]$ & 61 [4.9] & 82.08 & $<0.000^{*}$ \\
\hline Stye & $4[1.6]$ & $2[1.0]$ & $0[0]$ & $3[0.9]$ & $0[0]$ & $9[0.7]$ & 6.349 & 0.50 \\
\hline Squint & $2[0.8]$ & $0[0]$ & $3[1.1]$ & $3[0.9]$ & $2[1.3]$ & $10[0.8]$ & 2.793 & 0.903 \\
\hline $\begin{array}{c}\text { Conjunctival } \\
\text { Xerosis }\end{array}$ & $11[4.3]$ & 8 [4.2] & 4 [1.5] & $11[3.2]$ & $0[0]$ & $34[2.8]$ & 9.886 & 0.1959 \\
\hline Total & $114[44.4]$ & $76[39.4]$ & $101[37.4]$ & $133[38.1]$ & 59 [38.3] & $483[39.6]$ & & \\
\hline & & Table & ather's Lit & acy in Relc & to Eye Prob & & & \\
\hline
\end{tabular}

\begin{tabular}{|c|c|c|c|c|c|c|c|c|}
\hline \multirow[b]{2}{*}{ Eye Problems } & \multicolumn{5}{|c|}{ Mother's Literacy } & \multirow[b]{2}{*}{$\begin{array}{c}\text { Total } \\
\mathbf{n}=1254 \\
{[\%]}\end{array}$} & \multirow[b]{2}{*}{$\begin{array}{c}\chi^{2} \\
\text { (df-4) }\end{array}$} & \multirow[b]{2}{*}{$\begin{array}{c}p \\
\text { Value }\end{array}$} \\
\hline & \begin{tabular}{|c|} 
Illiterate \\
$\mathbf{n}=656$ \\
{$[\%]$} \\
\end{tabular} & $\begin{array}{c}\text { Primary } \\
n=292 \\
{[\%]}\end{array}$ & $\begin{array}{c}\text { Middle } \\
\text { n = } 163 \\
{[\%]}\end{array}$ & $\begin{array}{c}\text { Matric } \\
n=105 \\
{[\%]}\end{array}$ & $\begin{array}{c}\geq \text { Intermediate } \\
\mathbf{n}=\mathbf{3 8} \\
{[\%]}\end{array}$ & & & \\
\hline Defective Vision & $95[14.5]$ & $36[12.3]$ & $18[11]$ & $15[14.3]$ & $4[10.5]$ & $168[13.4]$ & 3.25 & 0.904 \\
\hline $\begin{array}{l}\text { Squamous } \\
\text { Blepharitis }\end{array}$ & 75 [11.4] & 33 [11.3] & 24 [14.7] & 13 [12.4] & 8 [21.1] & $153[12.2]$ & 6.098 & 0.297 \\
\hline Conjunctivitis & $30[4.6]$ & $16[5.5]$ & $7[4.3]$ & $6[5.7]$ & $0[0]$ & $59[4.7]$ & 2.58 & $>0.50$ \\
\hline $\begin{array}{c}\text { Vernal } \\
\text { Conjunctivitis }\end{array}$ & $43[6.6]$ & 14 [4.8] & $4[2.5]$ & $1[0.9]$ & $1[2.6]$ & $63[5.0]$ & 9.29 & $0.056^{*}$ \\
\hline Stye & $5[0.7]$ & $2[0.6]$ & $1[0.6]$ & $1[0.9]$ & $0[10]$ & $9[0.7]$ & 0.495 & 0.992 \\
\hline Squint & $6[0.9]$ & $3[1.0]$ & $1[0.6]$ & $0[0]$ & $0[0]$ & $10[0.8]$ & 1.641 & 0.896 \\
\hline $\begin{array}{c}\text { Conjunctival } \\
\text { Xerosis }\end{array}$ & $23[3.5]$ & 8 [2.7] & $0[0]$ & 2 [1.9] & $1[2.6]$ & 34 [2.7] & 7.652 & 0.176 \\
\hline Total & 277 [42.2] & $112[38.4]$ & 55 [33.7] & $38[36.8]$ & $14[36.8]$ & $486[38.8]$ & & \\
\hline \multicolumn{9}{|c|}{ Table VI. Mother's Literacy in Relation to Eye Problems } \\
\hline
\end{tabular}




\begin{tabular}{|c|c|c|c|c|c|c|c|c|c|}
\hline \multirow[b]{2}{*}{ Eye Problems } & \multicolumn{6}{|c|}{ Occupation } & \multirow[b]{2}{*}{$\begin{array}{c}\text { Total } \\
\mathbf{n}=\mathbf{1 2 2 3} \\
{[\%]}\end{array}$} & \multirow[b]{2}{*}{$\begin{array}{c}\chi^{2} \\
\text { (df-5) }\end{array}$} & \multirow[b]{2}{*}{$\begin{array}{c}\mathbf{P} \\
\text { Value }\end{array}$} \\
\hline & $\begin{array}{c}\text { Farmer } \\
\text { n = 437 } \\
{[\%]}\end{array}$ & $\begin{array}{c}\text { Labourer } \\
\mathrm{n}=435 \\
{[\%]}\end{array}$ & $\begin{array}{c}\text { Shop } \\
\text { Keeper } \\
\text { n = 163 } \\
{[\%]}\end{array}$ & $\begin{array}{c}\text { Govt. Job } \\
\text { n = 71 } \\
{[\%]}\end{array}$ & $\begin{array}{c}\text { Driver } \\
\text { n = 41 } \\
{[\%]}\end{array}$ & $\begin{array}{c}\text { Others } \\
\text { n= } 76 \\
{[\%]}\end{array}$ & & & \\
\hline Defective Vision & 62 [14.2] & 60 [13.8] & $16[9.8]$ & 7 [9.9] & 5 [12.2] & 12 [15.8] & $162[13.3]$ & 3.29 & $>0.50$ \\
\hline $\begin{array}{l}\text { Squamous } \\
\text { Blepharitis }\end{array}$ & 57 [13.0] & $60[13.8]$ & $15[3.1]$ & $5[7.0]$ & $1[2.4]$ & 13 [17.1] & $151[12.4]$ & 11.652 & 0.167 \\
\hline Conjunctivitis & $23[5.3]$ & $22[5.1]$ & $5[3.1]$ & $2[2.8]$ & $1[2.4]$ & $3[4.0]$ & $56[4.6]$ & 2.69 & $>0.50$ \\
\hline $\begin{array}{c}\text { Vernal } \\
\text { Conjunctivitis }\end{array}$ & $19[4.3]$ & $22[5.1]$ & $10[6.1]$ & $4[5.6]$ & $2[4.9]$ & $4[5.3]$ & $61[5.0]$ & 1.03 & $>0.50$ \\
\hline Stye & $4[0.9]$ & $4[0.9]$ & $0[0]$ & $0[0]$ & $0[0]$ & $1[1.3]$ & $9[0.7]$ & 3.304 & 0.914 \\
\hline Squint & $4[0.9]$ & $4[0.9]$ & $0[0]$ & $1[1.4]$ & $1[2.4]$ & $0[0]$ & $10[0.8]$ & 4.195 & 0.839 \\
\hline $\begin{array}{c}\text { Conjunctival } \\
\text { Xerosis }\end{array}$ & $12[2.7]$ & $15[3.5]$ & $3[1.8]$ & $1[1.4]$ & $0[0]$ & $3[4.0]$ & 34 [2.8] & 3.566 & 0.894 \\
\hline Total & $181[41.4]$ & $187[42.8]$ & $49[30.1]$ & 20 [28.2] & $10[24.4]$ & $36[47.4]$ & $483[39.5]$ & & \\
\hline \multicolumn{10}{|c|}{ Table VII. Relation of Eye Problems with Father's Occupation } \\
\hline
\end{tabular}

\section{DISCUSSION}

The present study observed that out of total 451 children $(35.65 \%)$ were having one or more eye problems. This finding is similar to those of Shreshtha et al ${ }^{6}(34.2 \%)$. Gupta Madhu et al7 observed 31.6\%, Rajesh et al ${ }^{8}$ observed 24.6\%, Kuruvilla et $\mathrm{al}^{9}$ observed $12.5 \%$, Pankaj Kumar et al ${ }^{10}$ found $11.5 \%$ and Nepal et al ${ }^{11}$ observed $11 \%$ prevalence of ocular morbidity in school children. In this study, overall prevalence of ocular morbidity was $39.9 \%$.

Khurana et al $^{12}$ observed $58.77 \%$ ocular morbidity in 1984 in school children (4 - 18 yrs.) of Rohtak City. The observed difference may be due to difference of studied age group and urban area and the study being old.

In this study, most of the morbidities (51\%) were found in oldest age group (13 - 15 yrs.), while least morbidities $(29.4 \%)$ in the youngest age group (6 - 10 yrs.). Strong significant association was found with increase in age group in cases of defective vision and conjunctival xerosis. Prasanna et al ${ }^{13}$ also showed an increase in ocular morbidity with age.

Fathers of 503 students (39.8\%) were educated up to matriculation and above. While mothers of only 143 students $(11.3 \%)$ were educated up to this level. Vernal Conjunctivitis shows significant association with father's literacy. Pankaj et $\mathrm{al}^{10}$ and Deshpande et al ${ }^{14}$ observed a significant association of ocular morbidity with mother's and father's literacy status. Dandona et al ${ }^{15}$ Murthy et $\mathrm{al}^{16}$ and Trivedi et al ${ }^{17}$ observed a significant association of myopia in the child with higher educational status of the father.

In the present study, the prevalence of squamous blepharitis was found to be $12.3 \%$, which was much more than the prevalence found in other studies, i.e. Prajapati $P$ et al ${ }^{18}$ observed $5.7 \%$, Rajesh et al ${ }^{8}$ observed $1.3 \%$, Kumar R et al ${ }^{19}$ observed $1 \%$, Deshpande et al ${ }^{14}$ observed $0.96 \%$, Trivedi et $\mathrm{al}^{17}$ observed $0.93 \%$ and Kuruvilla et al $^{9}$ observed $0.14 \%$ prevalence of squamous blepharitis. The difference may be because of rural area chosen for the present study.

In this study, the prevalence of conjunctivitis was found to be $4.7 \%$. This is similar to those of Kumar $\mathrm{R}$ et al, ${ }^{19}$ where in the prevalence was found to be $4.6 \%$. Trivedi et al 17 observed $5.1 \%$, Rajesh et $\mathrm{al}^{8} 4.3 \%$, Prajapati $\mathrm{P}$ et al ${ }^{18} 3.8 \%$, Deshpande et al ${ }^{14} 2.57 \%$, Prasanna et al ${ }^{13} 2.3 \%$, Shaffi et al 20 $1.5 \%$, Kuruvilla et al ${ }^{9}$ observed $1.1 \%$ prevalence and Khurana et al 12 observed $23.43 \%$ prevalence.
In the present study, the prevalence of vernal conjunctivitis was found to be $5.1 \%$. This is higher than that found in other studies like Kehinde AV et al ${ }^{21}$ (4.55\%), Shaffi et $\mathrm{al}^{20}(0.7 \%)$ and Kuruvilla et $\mathrm{al}^{9}(0.66 \%)$. The higher prevalence may be because the spring season was also included in this study.

In the present study the prevalence of stye was found to be $0.7 \%$, which is slightly lower than that reported by Deshpande et $\mathrm{al}^{14}(1.74 \%)$ and Kumar R et $\mathrm{al}^{19}(1.3 \%)$. Rajesh et al ${ }^{11}$ found $1.0 \%$ and Madhu et al ${ }^{7}$ observed $0.9 \%$ prevalence.

In this study, the prevalence of strabismus was found to be $0.8 \%$. This finding is similar to those of Prasanna 13 $(0.77 \%)$. Khurana et al ${ }^{12}$ reported $0.66 \%$, Murthy et al 16 reported $0.53 \%$, Kuruvilla et al, 9 Gupta Madhu et al ${ }^{7}$ and Singh Harpal et $\mathrm{al}^{22}$ reported $2.02 \%, 2.5 \%$ and $2.08 \%$ prevalence of strabismus respectively. In the present study, strabismus was more prevalent in lower age groups.

In this study the prevalence of Vit. A deficiency was found to be $5.4 \%$, which is more than Kehinde AV $^{21}$ (4.55\%). Singh Harpal $^{22}$, Deshpande et $\mathrm{al}^{14}$ and Prajapati $\mathrm{P}$ et al ${ }^{18}$ recorded much higher prevalence of $13.66 \%, 25.58 \%$ and $29.3 \%$ respectively in school children.

In the present study, night blindness was observed in $2.6 \%$ children. This finding is greater than $0.30 \%$ as reported by Khurana et al. 12

Conjunctival xerosis was recorded in $2.8 \%$ students in this study. Nepal et $\mathrm{al}^{11}$ recorded $0.36 \%$ prevalence. In the present study, conjunctival xerosis was found to be more in higher age groups and this association was significant.

Not a single case of Bitot's spot was recorded in this study. This finding is similar to those of Shaffi et $\mathrm{al}^{20}{ }^{20}$ wherein the Bitot's spots were prevalent in only $0-5$ yrs. of age and no case was found in $6-15$ yrs. of age group. Trivedi et al ${ }^{18}$ recorded $3.9 \%$ prevalence. Kuruvilla et $\mathrm{al}^{9}$ recorded $0.43 \%$ prevalence.

In this study, the prevalence of corneal opacity was found to be $0.15 \%$. This finding is quite similar to $0.18 \%$ recorded by Khurana et al. ${ }^{12}$ Kehinde et $\mathrm{al}^{21}$ recorded $0.08 \%$ and Singh Harpal $^{22}$ observed much higher prevalence $5.86 \%$ in school children.

In the present study, the prevalence of ocular injuries was found to be $2.13 \%$. Deshpande et al ${ }^{14}$ and Singh Harpal et al ${ }^{22}$ reported $3.48 \%$ and $5.33 \%$ prevalence. In this study, 
prevalence of ocular injuries was more in boys as compared to girls and this difference is statistically significant. The reason may be the higher outdoor exposure in boys. Nystagmus was found in 5 students $(0.4 \%)$ in this study.

\section{CONCLUSION}

Ocular morbidities among school going children can be easily identified by regular eye screening programmes and if treated promptly reduces the visual disabilities. The present study shows defective vision in one or both eyes and squamous blepharitis are the main causes of visual disability in school children. The eye health awareness among school children and school teachers help in reducing ocular morbidity, so that they can attain their full potential in the course of their education.

\section{Recommendations}

Eye checkup should be done at the time of entry in school and periodic evaluation of eye screening programme should be done. A good functioning referral system should be attached to the school health services. School health records should be maintained for followup. Community based vision screening programme should be encouraged and provision of good quality and affordable spectacles should be an integral part of the vision screening programme. Chaupal and other religious places can be used for spreading awareness regarding common eye diseases and advocating the need to focus on the health status of the growing children.

\section{REFERENCES}

[1] Vision screening in school children. A training module. New Delhi: The Typesetters 1992: p. 5.

[2] Government of India. National Programmeme for control of blindness. Quarterly Newsletter 2007; Vol. 2.

[3] VISION 2020: the right to sight-how does vision 2020 work? http://www.vision2020.org

[4] Universal eye health: a global action plan 2014-2019. http://www.who.int/blindness/AP201419English.pdf

[5] Health dialogue. A forum for the exchange of new and views on primary health care in India. Inveno 2006;44:1.

[6] Shrestha RK, Joshi MR, Ghising R, et al. Ocular morbidity among children studying in private school of Kathmandu valley: a prospective cross sectional study. Nepal Med Coll J 2006;8(1):43-6.

[7] Madhu G, Bhupinder PG, Anil C, et al. Ocular morbidity among school children in Shimla, Himachal, north India. Indian Journal of Ophthalmology 2009;57(2):133-8.
[8] Kumar R, Dabas P, Mehra M, et al. Ocular morbidity amongst primary school children in Delhi. Health and population 2007;30(3):222-9.

[9] Kuruvilla J, Rao PN. Ocular morbidity in school children in rural coastal area of Karnataka. Indian J Ophthalmol 1978;26(2):9-12.

[10] Kumar P, Prasad P, Dixit AK, et al. Demographic profile of ocular morbidity in school children in India. Sch J App Med Sci 2013;1(5):645-52.

[11] Nepal BP, Koirala S, Adhihary S, et al. Ocular morbidity in school children in Kathmandu. Br J Ophthalmol 2003;87(5):531-4.

[12] Khurana AK, Sikka KL, Parmar IPS, et al. Ocular morbidity among school children in Rohtak city. Ind J Pub Health 1984;28(4):217-20.

[13] Kamath PBT, Prasad GBS, Deepthi R, et al. Prevalence of ocular morbidity among school going children (6-15 years) in rural area of Karnataka, south India. Int J Pharm Biomed Res 2012;3(4):209-12.

[14] Jayant DD, Malathi K. Prevalence of ocular morbidities among school children in rural area of north Maharashtra in India. National Journal of Community Medicine 2011;2(2):249-54.

[15] Dandona R, Dandona L, Srinivas M, et al. Refractive error in children in a rural population in India. Invest Ophthalmol Vis Sci 2002;43(3):615-22.

[16] Murthy GVS, Gupta SK, Ellwein LB, et al. Refractive error in children in an urban population in New Delhi. Invest Ophthalmol Vis Sci 2002;43(3):623-31.

[17] Trivedi V, Zalawadiya S, Bhatt JV, et al. Prevalence of refractive errors in children of rural \& urban areas of Gujarat: a population based study. http://openmed.nic.in/1933/01/bhatt 1.pdf.

[18] Prajapati P, Oza J, Prajapati J, et al. Prevalence of ocular morbidity among school adolescents of Gandhinagar district, Gujarat. Online Journal of Health and Allied Sciences 2010;9(4):102-3.

[19] Kumar R, Mehra M, Dabas P, et al. A study of ocular infections amongst primary school children in Delhi. Indian J Commun Dis 2004;36(2):121-6.

[20] Shaffi M, Bejiga A. Common eye diseases in children of rural community of Goro District, Central Ethiopia. Ethiop J Health Dev 2005;19(2):148-52.

[21] Kehinde AV, Ogwurike SC, Eruchalu UV, et al. School eye health screening in Kaduna northern Nigeria. Nigerian Journal of Surgical Research 2005;7(12):191-4.

[22] Singh H. Pattern of ocular morbidity in school children in central India. National Journal of Community Medicine 2011;2(3):429-31. 